\title{
Sugammadex ED90 dose to reverse the rocuronium neuromuscular blockade in obese patients
}

\section{Dose ED90 de Sugamadex para reverter o bloqueio neuromuscular com rocurônio em pacientes obesos}

Mauro Prado da Silva ${ }^{1}$; Christiano Matsui ; Daniel Dongiou Kim"; Joaquim Edson Vieira ${ }^{2}$; Carlos Alberto Malheiros ${ }^{1}$; Ligia Andrade Silva Telles Mathias ${ }^{1}$.

\section{A B S T R A C T}

\begin{abstract}
Objective: to determine the ED90 (minimum effective dose in $90 \%$ of patients) of sugammadex for the reversal of rocuronium-induced moderate neuromuscular blockade (NMB) in patients with grade III obesity undergoing bariatric surgery. Methods: we conducted a prospective study with the biased coin up-and-down sequential design. We chosen the following doses: $2.0 \mathrm{mg} / \mathrm{Kg}, 2.2 \mathrm{mg} / \mathrm{Kg}, 2.4 \mathrm{mg} / \mathrm{Kg}$, $2.6 \mathrm{mg} / \mathrm{Kg}, 2.8 \mathrm{mg} / \mathrm{Kg}$. The complete reversal of rocuronium-induced NMB considered a T4/T1 ratio $\geq 0.9$ as measured by TOF. After induction of general anesthesia and calibration of the peripheral nerve stimulator and accelerometer, we injected rocuronium $0.6 \mathrm{mg} / \mathrm{kg}$. We administered propofol and remifentanil by continuous infusion, and intermittent boluses of rocuronium throughout the procedure. Results: we evaluated 31 patients, of whom 26 had displayed successful reversal of the NMB with sugammadex, and failure in five. The mean time to complete moderate NMB reversal was 213 seconds (172-300, median 25-75\%). The ED90 of sugammadex calculated by regression was $2.39 \mathrm{mg} / \mathrm{kg}$, with a $95 \%$ confidence interval of $2.27-2.46 \mathrm{mg} / \mathrm{kg}$. Conclusion: the ED90 of sugammadex in patients with grade III obesity or higher was $2.39 \mathrm{mg} / \mathrm{kg}$.
\end{abstract}

Keywords: Dose-Response Relationship, Drug. Obesity. Cyclodextrins.

\section{INTRODUCTION}

$\mathrm{T}$ pathophysiological changes determined by obesity can affect the distribution and elimination of medications ${ }^{1,2}$. The majority of drugs with high lipid solubility have a high distribution volume ${ }^{3}$. Measures of weight correction to indicate the best scheme of drug administration in obese patients have been proposed ${ }^{4-6}$. A simple and easy method of calculating ideal body weight (IBW) considers height in centimeters (cm) minus 100 for men and height in centimeters less 110 for women?

Sugamadex, a selective binding agent that reverses rocuronium-induced neuromuscular blockade $(\mathrm{NMB})$, can be rapidly distributed into the extracellular fluid, which should therefore be considered as its distribution volume $(D V)^{8}$. This substance is used in adults of normal weight at $2 \mathrm{mg} / \mathrm{kg}$ to promote reversion of moderate NMB, measured by the train-of-four (TOF) stimulus sequence $(T 4 / T 1 \geq 0.9)$; at $4 \mathrm{mg} / \mathrm{kg}$ for reversal of deep NMB; and at a dose of $16 \mathrm{mg} / \mathrm{kg}$ for immediate reversal of rocuronium-induced $\mathrm{NMB}^{9-13}$.
Results in patients with grade III obesity submitted to laparoscopic bariatric surgery under NMB indicated an optimal dose of $2 \mathrm{mg} / \mathrm{kg}$ of sugammadex based on $140 \%$ of the IBW for patients with moderate neuromuscular blockade ${ }^{14}$. However, a prospective observational study found that $23.4 \%$ of patients required a second dose of sugammadex to reverse moderate NMB over a two-minute time interval when a dose of $2 \mathrm{mg} /$ $\mathrm{kg}$ was used in comparison with the time of reversion between non-obese subjects ${ }^{15}$.

There are sequential evaluation methods for binary response variables used to determine the concentration or dose associated with the $50 \%$ point of the dose-response curve. The up-and-down method is commonly used in anesthesia research ${ }^{16}$. Briefly, the first patient with a positive response to the received dose will indicate an initial lower subsequent dose to the next patient; if the patient does not have a positive response, the next will receive a higher dose. This procedure is repeated until the end of the determined experiment ${ }^{17}$. 
Table 1. Anthropometric data and procedures times (median, 25-75\%).

\begin{tabular}{lcc}
\hline & Successes $(\mathrm{n}=26)$ & Failures $(\mathrm{n}=5)$ \\
\hline Age $($ years $)$ & $42(35-45)$ & $45(40-52)$ \\
Height $(\mathrm{m})$ & $1.62(1.55-1.73)$ & $1.59(1.59-1.67)$ \\
Weight $(\mathrm{kg})$ & $126.5(110-149)$ & $130(124-130)$ \\
BMI $\left(\mathrm{kg} / \mathrm{cm}^{2}\right)$ & $49.3(44.3-52.0)$ & $46.7(46.6-51.4)$ \\
Time of surgery $(\mathrm{min})$ & $194.5(158.5-223.7)$ & $220(203.0-225.0)$ \\
Anesthesia time $(\mathrm{min})$ & $240(206-295)$ & $300(270-305)$ \\
Time to awake $(\mathrm{min})$ & $10.5(7.2-15.7)$ & $12(10.0-20.0)$ \\
Rocuronium total dose $(\mathrm{mg})$ & $96(84.2-117.8)$ & $100(79.2-119.4)$ \\
Sugamadex total dose $(\mathrm{mg})$ & $123.6(108-160.8)$ & $117.6(107.8-136.8)$ \\
\hline
\end{tabular}

BMI: body mass index.

Previous studies have suggested that reversal of NMB in morbidly obese patients could be achieved at $4 \mathrm{mg} / \mathrm{kg}$ for deep blockade considering the ideal body weight, or $2 \mathrm{mg} / \mathrm{kg}$, regardless of which body weight is considered, ideal or actual18,19.

The aim of this study was to determine the minimum effective dose of sugammadex in $90 \%$ of obese patients (ED 90) required to complete the reversal of rocuronium-induced moderate neuromuscular blockage using the up-and-down design of biased coin (BCD) in patients with grade III obesity submitted to bariatric surgery. We also recorded the mean time to NMB reversal in these patients with obesity grade III or higher.

\section{METHODS}

We conducted a prospective study using the biased coin up-and-down sequential method (BCD) to determine the ED90 of patients with obesity grade III or higher undergoing bariatric surgery receiving sugammadex for the reversal of moderate neuromuscular blockade induced by rocuronium. We studied patients operated at the Central Hospital of the Brotherhood of the São Paulo Holy Home of Mercy, from January to October 2013. The estimated sample size considered 20 patients to determine the lowest effective dose ${ }^{18}$.

Inclusion criteria were patients older than 18 years and under 60 years, body mass index $\geq 40 \mathrm{~kg} / \mathrm{m}^{2}$, with indication of bariatric surgery and who signed the informed consent term. We did not include Patients with a history of neuromuscular disease, use of medicinal products that could interfere with neuromuscular transmission, allergy to aminosteroid-class neuromuscular blocking agents, any anticipated difficulties in managing the airways, or renal failure.

We chose the doses of sugammadex to reach the decile $0.9: 2.0 \mathrm{mg} / \mathrm{kg} ; 2.2 \mathrm{mg} / \mathrm{kg} ; 2.4 \mathrm{mg} / \mathrm{kg} ; 2.6 \mathrm{mg} /$ $\mathrm{kg} ; 2.8 \mathrm{mg} / \mathrm{kg}$, and also considering patients' IBW. The first patient in the study received a dose of $2.4 \mathrm{mg} / \mathrm{kg}$ and, if there was a negative response, the next patient would be considered to receive a next higher dose of $2.6 \mathrm{mg} / \mathrm{kg}$. However, in the case where $2.4 \mathrm{mg} / \mathrm{kg}$ produced a positive response, the next patient would be randomized with a $10 \%$ probability of receiving the next dose of $2.2 \mathrm{mg} /$ $\mathrm{kg}$ and $90 \%$ probability of receiving the same dose of $2.4 \mathrm{mg} / \mathrm{kg}$. We repeated this procedure subsequently until the end of the study ${ }^{17}$.

Complete NMB reversal occurred when the patient had a TOF T4/T1 ratio $\geq 0.9$ within eight minutes of sugammadex infusion at the prescribed dose. In case of failure, the same dose was repeated until complete neuromuscular blockade reversal.

The anesthesia technique included denitrogenation with $100 \%$ oxygen in proclivity position, followed by intravenous (IV) infusion of fentanyl $5 \mu \mathrm{g} / \mathrm{kg}$ IBW and propofol $2 \mathrm{mg} / \mathrm{kg}$ total body weight. Soon after calibration of the peripheral nerve stimulator and accelerometer, we injected rocuronium IV at the dose of $0.6 \mathrm{mg} / \mathrm{kg}$ of IBW 
Table 2. Sugamadex dose and time to complete the reversal of neuromuscular blockade (median, 25 to 75 percentile $-n=31$ )

\begin{tabular}{cccccc}
\hline Dose $(\mathrm{mg} / \mathrm{kg})$ & Success & $\begin{array}{c}\text { Subjects } \\
\text { studied }\end{array}$ & Observed probability & $\begin{array}{c}\text { PAVA-adjusted } \\
\text { probability }\end{array}$ & Time to reversion (s) \\
\hline 2.20 & 0 & 3 & 0.0 & 0.0 & - \\
2.40 & 23 & 25 & 0.92 & 0.92 & $213(172-300)$ \\
2.60 & 3 & 3 & 1.0 & 1.0 & $150(150-229)$ \\
\hline
\end{tabular}

PAVA: pooled-adjacent-violators algorithm.

to NMB. We maintained anesthesia with propofol 2 to $6 \mathrm{mg} / \mathrm{kg} / \mathrm{h}$ to keep the bispectral index (BIS) at 40 to 60 , remifentanil 0.1 to $0.3 \mu \mathrm{g} / \mathrm{kg} / \mathrm{h}$ and intermittent boluses of rocuronium at $0.3 \mu \mathrm{g} / \mathrm{kg}$ of IBW, still adjusted to maintain a maximum of only two responses, $\mathrm{T} 1$ and $\mathrm{T} 2$, in TOF. Patients were referred to a stay of no less than six hour in the post-anesthetic recovery unit (PACU), in which the neuromuscular function was clinically evaluated by the TOF, both on admission and on discharge from the unit.

Patients were monitored with cardioscope, pulse oximetry, capnography (in ventilation to maintain $\mathrm{ETCO}_{2}$ between 35 and $40 \mathrm{mmHg}$ ), noninvasive blood pressure, central temperature (forced warm air blanket maintained in the upper body), BIS, TOF (Electrodes on the ulnar nerve and accelerometer on the thumb). The four-stimulus sequence was monitored every five minutes after calibration of the monitor for each patient, and immediately after the infusion of sugammadex at 15-second intervals until T4/T1 $\geq 0.9$ (TOFWatch SX, Organon Ltd Dublin, Ireland).

We used the statistical software $R$ version 3.0.2 (R Foundations for Statistical Computing, Vienna, Austria), as well as the Sigma Stat statistical package for Windows version 2.03 (SPSS Inc., Chicago, IL, USA). We used the isotonic regression functions with the pooledadjacent-violators algorithm (PAVA) to determine the ED90, and bootstrapping to calculate the respective 95\% confidence interval with the statistical program $\mathrm{R}^{17-19}$.

This study was approved by the Ethics in Research Committee of the Brotherhood of the São Paulo Holy Home of Mercy and was registered at ClinicalTrials. gov under the number: NCT02568345.

\section{RESULTS}

The ED90 of sugammadex calculated by isotonic regression was $2.39 \mathrm{mg} / \mathrm{kg}$, with a $95 \%$ confidence interval of $2.27-2.46 \mathrm{mg} / \mathrm{kg}$ ), calculated by the bootstrapping method with 9,999 replicates of the sample. There were no patients with residual neuromuscular blockade at any of the three time points studied after complete reversal of moderate NMB with sugammadex.

Thirty-one patients completed the study, 24 females (77\%) and seven males (23\%). Anthropometric data and procedure times (median, 25 to $75 \%$ ) did not differ between groups (Table 1). Twenty-six patients achieved complete reversal of moderate neuromuscular blockade with sugammadex (77\% female), and five patients failed to achieve it ( $80 \%$ female), and the time for reversal was smaller with the higher dose (Figure 1, Table 2).

\section{DISCUSSION}

This study establishes the effective ED90 dose of sugammadex at $2.39 \mathrm{mg} / \mathrm{kg}$ (95\% Cl: $2.27-2.46 \mathrm{mg} /$ $\mathrm{kg}$ ) for the reversal of rocuronium-induced moderate neuromuscular blockade in obese patients $\geq$ grade III. The biased coin design (BCD) allowed the use of small samples, reducing the time of execution and also the number of individuals tested with ineffective doses, which is interesting from an ethical point of view.

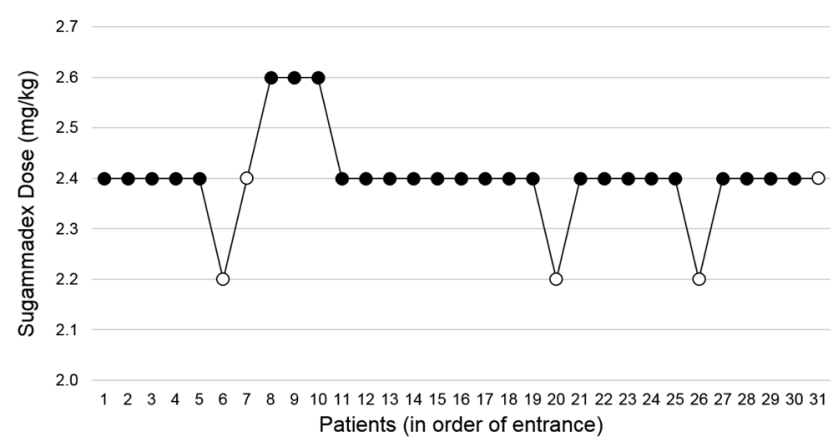

Figure 1. Up-and-down sequence of the biased coin for administered doses (n=31). Empty circle: failure to reverse the lockade; Full circle: complete reversal of the blockade. 
In the classical up-and-down model, the doses tested are concentrated closer to the 0.5 decile (ED50), but the estimated probabilistic dose with higher efficiency should be situated close to decile 0.9 (ED90) ${ }^{17}$. However, The efficiency of this procedure is disputed by some authors ${ }^{18,20}$. Most studies with this approach in anesthesiology study 20-40 patients ${ }^{21-29}$.

A recent study did not point out the total dose of rocuronium ${ }^{14}$, while other investigations point to an average of $97.5 \mathrm{mg}$ of rocuronium for 120 minutes of surgery duration ${ }^{15}$. The present study observed individuals who had the moderate neuromuscular blockage successfully reversed after receiving $100.8 \mathrm{mg}$ of rocuronium for 194 minutes of surgery duration. An additional variable that could be difficult to compare relates to the definition of ideal body weight, since we did not base our study on expected tables for height and weight ${ }^{30}$. Nevertheless, our results confirm recent investigations suggesting sugammadex doses in a range of 2-4 mg/kg of ideal body weight ${ }^{18,19}$.

Some limitations of this study are the lack of investigation for the minimal effective dose in other clinically relevant situations, such as during superficial or deep neuromuscular blockade in individuals with obesity $\geq$ grade III. Additional studies may examine these variables.

In conclusion, for obese grade III or higher, the ED90 dose for sugammadex to reverse rocuroniuminduced neuromuscular blockade was $2.39 \mathrm{mg} / \mathrm{kg}$ within a mean infusion time of 213 seconds.

\title{
R E S U M O
}

\begin{abstract}
Objetivos: determinar a ED90 (dose mínima eficaz em 90\% dos pacientes) de sugamadex para a reversão de bloqueio neuromuscular (BNM) moderado induzido pelo rocurônio em pacientes com obesidade grau III submetidos à cirurgia bariátrica. Métodos: estudo prospectivo com o método de projeção sequencial para cima e para baixo da moeda enviesada. As seguintes doses foram escolhidas: 2,0mg/ $\mathrm{kg}^{-1}, 2,2 \mathrm{mg} / \mathrm{kg}^{-1}, 2,4 \mathrm{mg} / \mathrm{kg}^{-1}, 2,6 \mathrm{mg} / \mathrm{kg}^{-1}, 2,8 \mathrm{mg} / \mathrm{kg}^{-1}$. A reversão completa de BNM induzido por rocurônio considerou uma relação T4/ T1 $\geq 0,9$ na medida do TOF. Após a indução da anestesia geral e calibração do estimulador de nervo periférico e acelerômetro, rocurônio $0,6 \mathrm{mg} / \mathrm{kg}^{-1}$ foi injetado. Infusão contínua de propofol e remifentanil, e bolus intermitente de rocurônio foram injetados durante todo o procedimento. Resultados: trinta e um pacientes foram avaliados, 26 dos quais bem-sucedidos e cinco sem reversão completa do BNM moderado promovido pelo sugamadex. O tempo médio para completar reversão de BNM foi 213 segundos (172 a 300 segundos; mediana, 25-75\%). O ED90 de sugamadex calculado pela regressão foi de 2,39 mg/ $\mathrm{kg}^{-1} \mathrm{com}$ um intervalo de confiança de $95 \%$ (2,27 a $2,46 \mathrm{mg} / \mathrm{kg}^{-1}$ ). Conclusão: o ED90 de sugamadex em pacientes com obesidade grau III ou superior foi 2,39mg/ $\mathrm{kg}^{-1}$.
\end{abstract}

Descritores: Obesidade. Ciclodextrinas. Relação Dose-Resposta a Droga.

\section{REFERENCES}

1. Abernethy DR, Greenblatt DJ, Divoll M, Smith RB, Shader RI. The influence of obesity on the pharmacokinectics of oral alprazolam and triazolam. Clin Pharmacokinet. 1984;9(2):177-83.

2. Blouin RA, Kolpek JH, Mann HJ. Influence of obesity on drug disposition. Clin Pharm. 1987;6(9):706-14.

3. De Baerdemaeker LEC, Mortier EP, Struys MMRF. Pharmacokinectics in obese patients. Contin Educ Anesth Crit Care Pain. 2004;4(5):152-5.

4. Mosteller RD. Simplified calculation of body-surface area. N Engl J Med. 1987;317(17):1098.

5. Duffull SB, Dooley MJ, Green B, Poole SG, Kirkpatrick CM. A standard weight descriptor for dose adjustment in the obese patient. Clin Pharmacokinet. 2004;43(15):1167-78.

6. Janmahasatian S, Duffull SB, Ash S, Ward LC, Byrne NM, Green B. Quantification of lean bodyweight. Clin
Pharmacokinet. 2005;44(10):1051-65.

7. Pai MP, Paloucek FP. The origin of the "ideal" body weight equations. Ann Pharmacother. 2000;34(9):1066-9.

8. Alvarez A, Brodsky JB, Lemmens HJM, Morton JM, editors. Morbid Obesity: Peri-operative Management. 2nd ed. Cambridge, UK: Cambridge University Press; 2010. p.100-10.

9. Epemolu O, Bom A, Hope F, Mason R. Reversal of neuromuscular blockade and simultaneous increase in plasma rocuronium concentration after the intravenous infusion of the novel reversal agent Org 25969. Anesthesiology. 2003;99(3):632-7; discussion 6A.

10. Sorgenfrei IF, Norrild K, Larsen PB, Stensballe J, Ostergaard D, Prins ME, et al. Reversal of rocuronium-induced neuromuscular block by the selective relaxant binding agent sugammadex: a dose-finding and safety study. Anesthesiology. 2006;104(4):667-74. 
11. Nicholson WT, Sprung J, Jankowski CJ. Sugammadex: a novel agent for the reversal of neuromuscular blockade. Pharmacotherapy. 2007;27(8):1181-8.

12. de Boer HD, Driessen JJ, Marcus MA, Kerkkamp H, Heeringa $M$, Klimek M. Reversal of rocuronium-induced $(1.2 \mathrm{mg} / \mathrm{kg}$ ) profound neuromuscular block by sugammadex: a multicenter, dose-finding and safety study. Anesthesiology. 2007;107(2):239-44.

13. Donati F. Sugammadex: a cyclodextrin to reverse neuromuscular blockade in anaesthesia. Expert Opin Pharmacother. 2008;9(8):1375-86.

14. Van Lancker P, Dillemans B, Bogaert T, Mulier JP, De Kock M, Haspeslagh M. Ideal versus corrected body weight for dosage of sugammadex in morbidly obese patients. Anaesthesia. 2011;66(8):721-5.

15. Llauradó S, Sabaté A, Ferreres E, Camprubí I, Cabrera A. Sugammadex ideal body weight dose adjusted by level of neuromuscular blockade in laparoscopic bariatric surgery. Anesthesiology. 2012;117(1):93-8.

16. Dixon WJ, Mood AM. A method for obtaining and analyzing sensivity data. J Am Statist Assoc. 1948;43(241):109-26.

17. Pace NL, Stylianou MP. Advances in and limitations of up-and-down methodology: a précis of clinical use, study design, and dose estimation in anesthesia research. Anesthesiology. 2007;107(1):144-52.

18. Sanfilippo $M$, Alessandri $F$, Wefki Abdelgawwad Shousha AA, Sabba A, Cutolo A. Sugammadex and ideal body weight in bariatric surgery. Anesthesiol Res Pract. 2013;2013:389782.

19. Loupec T, Frasca D, Rousseau N, Faure JP, Mimoz O, Debaene B. Appropriate dosing of sugammadex to reverse deep rocuronium-induced neuromuscular blockade in morbidly obese patients. Anaesthesia. 2016;71(3):265-72.

20. Stylianou M, Proscham M, Flournoy N. Estimating the probability of toxicity at the target dose following an up-and-down design. Stat Med. 2003;22(4):535-43.

21. Stylianou $M$, Flournoy $N$. Dose finding using the biased coin up-and-down design and isotonic regression. Biometrics. 2002;58(1):171-7.

22. Garrett-Mayer E. The continual reassessment method for dose-finding studies: a tutorial. Clin Trials. 2006;3(1):57-71.
23. Hammer GB, Litalien C, Wellis V, Drover DR. Determination of the median effective concentration (EC50) of propofol during oesophagogastroduodenoscopy in childen. Paediatr Anaesth. 2001;11(5):549-53.

24. Kodaka M, Suzuki T, Maeyama A, Koyama K, Miyao $\mathrm{H}$. Gender differences between predicted and measured propofol C (P50) for loss of consciousness. J Clin Anesth. 2006;18(7):486-9.

25. Hennebry MC, Stocks GM, Belavadi P, Barnes J, Wray $\mathrm{S}$, Columb MO, et al. Effect of i.v. phenylephrine or ephedrine on the ED50 of intrathecal bupivacaine with fentanyl for cesarean section. Br J Anaesth. 2009;102(6):806-11.

26. George RB, McKeen D, Chaplin AC, McLeod L. Updown determination of the $\mathrm{ED}(90)$ of oxytocin infusions for the prevention of postpartum uterine atony in parturients undergoing Cesarian delivery. Can J Anaesth. 2010;57(6):578-82.

27. Renes SH, van Geffen GJ, Rettig HC, Gielen MJ, Scheffer GJ. Minimum effective volume of local anesthetic for shoulder analgesia by ultrasound-guided block at root C7 with assessment of pulmonary function. Reg Anesth Pain Med. 2010;35(6):529-34.

28. Tran DQ, Dugani S, Correa JA, Dyachenko A, Alsenosy N, Finlayson RJ. Minimum effective volume of lidocaine for ultrasound-guided supraclavicular block. Reg Anesth Pain Med. 2011;36(5):466-9.

29. Demirkaya M, Kelsaka E, Sarihasan B, Bek Y, Üstün E. The optimal dose of remifentanil for acceptable intubating conditions during propofol induction without neuromuscular blockade. J Clin Anesth. 2012;24(5):392-7.

30. 1983 metropolitan height and weight tables. Stat Bull Metrop Life Found. 1983;64(1):3-9.

Received in: 22/09/2016

Accepted for publication: 11/10/2016

Conflict of interest: none.

Source of funding: none.

\section{Mailing address:}

Joaquim Edson Vieira

E-mail: joaquimev@usp.br joaquim.vieira@fm.usp.br 